\title{
Pulmonary giant cells and traumatic asphyxia
}

\author{
P. Betz, G. Beier, W. Eisenmenger \\ Department of Legal Medicine, University of Munich, Frauenlobstrasse 7a, D-80337 Munich, Germany
}

Received September 20, 1993 / Received in revised form February 1, 1994

Summary. A morphometrical analysis was performed to elucidate the significance of pulmonary polynuclear giant cells as a histological sign of asphyxiation. A total of 13 cases of homicidal strangulation of throttling, 8 cases of traumatic asphyxia due to chest compression and 10 control cases (cause of death: severe head injury, no signs of aspiration or other relevant pulmonary alterations, smokers and non-smokers) were investigated. The number of alveolar macrophages containing 1 or 2 nuclei and of polynuclear giant cells per microscopic field $(0.000025$ $\mathrm{cm}^{2}$ ) was estimated and a statistical evaluation was carried out. A considerable individual variation was observed in all groups with a tendency to higher numbers of cells in cases of smokers or advanced individual age. However, no significant differences were detectable in the content of alveolar macrophages and in particular of polynuclear giant cells between the asphyxiated individuals and the controls. Since polynuclear giant cells occurred in similar amounts in healthy, functionally normal lungs of non-asphyxiated individuals, the detection of such cells cannot be regarded as a reliable indicator for asphyxiation.

Key words: Asphyxiation - Alveolar macrophages - Giant cells - Morphometry

Zusammenfassung. Um die praktische Bedeutung des Nachweis von mehrkernigen Riesenzellen in der Lunge als histologisches Zeichen der Erstickung zu überprüfen, wurden 13 Fälle von Erdrosseln/Erwürgen, 8 Fälle von traumatischer Asphyxie infolge Thoraxkompression und 10 Kontrollen (Todesursache: schweres Schädel-Hirn-Trauma, keine Aspiration oder andere relevante Veränderungen der Lungen, Raucher und Nicht-Raucher) morphometrisch untersucht. Die Zahl der Alveolarmakrophagen mit einem oder zwei Kernen sowie von mehrkernigen Riesenzellen pro definierter Flächeneinheit $\left(0.000025 \mathrm{~cm}^{2}\right)$ wurde bestimmt und ein statistischer Vergleich durchgeführt. Es konnte eine erhebliche individuelle Variabilität mit zumeist höheren Zellzahlen bei Rauchern oder älteren Individuen beobachtet werden, statistisch signifikante Unterschiede in der Zahl der Alveolarmakrophagen und insbesondere der Riesenzellen zwischen den Er-

Correspondence to: P. Betz stickungsfällen und den Kontrollen ergaben sich jedoch nicht. Da mehrkernige Riesenzellen auch in den Lungen gesunder, nicht-erstickter Individuen zu beobachten sind, kann der Nachweis dieser Zelle u. E. nicht als verläßliches Zeichen für eine Erstickung angesehen werden.

Schlüsselwörter: Erstickung - Alveolarmakrophagen Riesenzellen - Morphometrie

\section{Introduction}

Since the occurrence of pulmonary polynuclear giant cells was described in experimental animals dying of prolonged hypoxia with a duration between $30 \mathrm{~min}$ and 12 hrs [7], the detection of such cells in the lungs of otherwise healthy individuals has been interpreted as a histological sign of (slow) asphyxiation [2, 5, 6, 8, 9].

In previous studies it was shown that polynuclear giant cells also occurred in the lungs of individuals without relevant pulmonary alterations who had died from other causes of death [1] and no increase in the number of such cells was found by semiquantitative evaluation in cases of strangulation/throttling or suffocation due to covering the head with plastic bags. To confirm and extent our prior results, a morphometrical analysis of the content of alveolar macrophages in lungs of individuals dying of strangulation/throttling or chest compression and of control cases was performed.

\section{Materials and methods}

The lungs of 31 individuals including 13 cases of homicidal strangulation or throttling, individual age 11-89 years (mean age 66 years), 8 cases of chest compression, individual age 22-71 years (mean age 40 years) and 10 control cases with almost immediate death following severe head injury, age $22-48$ years (mean age 30 years) were investigated. The postmortem interval did not exceed 3 days. Non-smokers and smokers identified by anamnestical data or the presence of so-called smoker-cells were included in all groups. No accompanying pulmonary alterations such as apparent infections or (especially in the control cases) signs of aspiration were detectable in our series. Resuscitation attempts were performed in some cases of chest compression (one successful resuscitation of a 22-year-old male who was covered by snow for approximately 
15 min and survived for 5 days and three cases of unsuccessful reanimation), but not in the group of strangulation/throttling or in the controls. The exact duration of the asphyxiation process could not be estimated, but survival times (interval between accident and individual death) up to 5 days were observed in the group of chest compression.

Two specimens were obtained from a peripheral and central part of the lower and upper lobe of the right lung (e.g. a total of 4 specimens) and fixed in 5\%-PBS-formaldehyde solution. Paraffin sections were prepared and stained with hematoxylin-eosin. The prussian blue-reaction was performed using $2 \%$ hydrochloric acid and $2 \%$ potassium-ferrocyanide and only cases without hemosiderin-positive alveolar marcophages were evaluated to exclude an influence of chronic heart disease on the development of giant cells. The alveolar macrophages were identified immunohistochemically using the monoclonal CD 68 antibody (Dako, Hamburg, Germany) according to the APAAP-method [4].

In each specimen 20 microscope fields (sized $0.000025 \mathrm{~cm}^{2}$ ) without larger blood vessels or bronchioles were randomly selected and the number of alveolar macrophages containing 1,2 or

Table 1. Mean values of alveolar macrophages in cases of strangulation/throttling ( $n=13$ ) (s, smokers; non-s, non-smokers)

\begin{tabular}{|c|c|c|c|c|}
\hline \multirow[t]{2}{*}{ Age (years) } & \multirow[t]{2}{*}{$\begin{array}{l}\text { Smoker/ } \\
\text { resuscitation }\end{array}$} & \multicolumn{3}{|c|}{$\begin{array}{l}\text { Alveolar macrophages/ } \\
0.000025 \mathrm{~cm}^{2}\end{array}$} \\
\hline & & 1 nucleus & 2 nuclei & $>2$ nuclei \\
\hline 11 & $-1-$ & 1.40 & 0.075 & 0.000 \\
\hline 12 & $-1-$ & 2.73 & 0.050 & 0.000 \\
\hline 13 & $-1-$ & 1.35 & 0.050 & 0.000 \\
\hline 22 & $-1-$ & 2.83 & 0.050 & 0.000 \\
\hline 30 & $+/-$ & 28.05 & 0.400 & 0.025 \\
\hline 31 & $-1-$ & 5.18 & 0.280 & 0.050 \\
\hline 42 & $-1-$ & 7.56 & 0.075 & 0.000 \\
\hline 45 & $? /-$ & 6.08 & 0.000 & 0.000 \\
\hline 46 & $+/-$ & 13.93 & 0.250 & 0.000 \\
\hline 53 & $+1-$ & 6.00 & 0.025 & 0.000 \\
\hline 60 & $+1-$ & 18.60 & 0.025 & 0.025 \\
\hline 62 & $-1-$ & 2.53 & 0.075 & 0.000 \\
\hline 89 & $-1-$ & 3.38 & 0.100 & 0.000 \\
\hline Mean value & $s+$ non-s & 7.66 & 0.112 & 0.008 \\
\hline Mean value & non-s & 3.37 & 0.094 & 0.006 \\
\hline
\end{tabular}

more nuclei (these cells were arbitrarily defined as polynuclear giant cells) was calculated using a 100-point grid (original size of the grid: $1 \mathrm{~cm}^{2}$, magnification of the evaluated specimen: $200 \times$ ).

A statistical analysis of the morphometrical data was performed using the non-parametric Mann-Whitney U-test for independent samples since a normal distribution of the parameters could not be assumed [10].

\section{Results}

\section{Immunohistochemical staining}

The reactivity for the CD 68 antibody, which specifically stains macrophages, was restricted only to alveolar macrophages, to the polynuclear giant cells in the alveoli and to some cells in the interstitial tissue which have to be regarded as resident macrophages. Pneumocytes of types I or II were negative.

\section{Morphometrical analysis}

The mean number of alveolar macrophages containing 1 nucleus showed a wide individual variation ranging from 2.38 to 30.48 cells per microscope field in the control group. Even though smokers showed a tendency to higher values, considerable numbers of alveolar macrophages could also be observed in non-smoking individuals in the control group (maximum value: approximately 16 cells/ $0.000025 \mathrm{~cm}^{2}$ ). In cases of advanced individual age higher numbers of such cells were generally detectable but low values were found (see Tables $1-3$ ) in the oldest individuals investigated (cases of strangulation/throttling, individual ages 62 and 89 years; non-smokers).

A differentiation between the number of alveolar macrophages in peripheral and central parts of the lungs was not performed due to a considerable intra- and interindividual variation.

\section{Statistical evaluation}

The statistical analysis was performed using the non-parametric Mann-Whitney U-test for independent samples [10]. No significant differences (significance level 95\%) in
Table 2. Mean values of alveolar macrophages in cases of chest compression $(n=8)$ (s, smokers; non-s, non-smokers)

\begin{tabular}{llllll}
\hline Age (years) & $\begin{array}{l}\text { Smoker/ } \\
\text { resuscitation }\end{array}$ & \multicolumn{2}{l}{$\begin{array}{l}\text { Alveolar macrophages/ } \\
0.000025 \mathrm{~cm}^{2}\end{array}$} & $\begin{array}{l}\text { Survival } \\
\text { time }\end{array}$ \\
\cline { 3 - 5 } & & 1 nucleus & 2 nuclei & $>2$ nuclei & \\
\hline 22 & $-/+$ & 7.85 & 0.100 & 0.025 & 5 days \\
31 & $-/-$ & $\mathbf{3 5 . 4 3}$ & 0.550 & $\mathbf{0 . 0 5 0}$ & $4 \mathrm{~h} 40 \mathrm{~min}$ \\
32 & $-/+$ & 4.30 & 0.225 & 0.000 & $16 \mathrm{~h}$ \\
36 & $-/+$ & 0.60 & 0.000 & 0.000 & $30 \mathrm{~min} ?$ \\
38 & $+/+$ & 34.63 & $\mathbf{0 . 9 7 5}$ & 0.025 & $45 \mathrm{~min}$ \\
42 & $-1-$ & 12.50 & 0.150 & 0.000 & $?$ \\
54 & $-/-$ & 10.83 & 0.300 & 0.000 & $?$ \\
71 & $-/-$ & 11.18 & 0.250 & $\mathbf{0 . 0 5 0}$ & $?$ \\
Mean value & s + non-s & 14.67 & 0.319 & 0.019 & \\
Mean value & non-s & 11.81 & 0.225 & 0.018 & \\
\hline
\end{tabular}


Table 3. Mean values of alceolar macrophages in control cases (severe head injury, $n=10$ ) (s, smokers; non-s, non-smokers)

\begin{tabular}{|c|c|c|c|c|}
\hline \multirow[t]{2}{*}{ Age (years) } & \multirow[t]{2}{*}{$\begin{array}{l}\text { Smoker/ } \\
\text { resuscitation }\end{array}$} & \multicolumn{3}{|c|}{$\begin{array}{l}\text { Alveolar macrophages/ } \\
0.000025 \mathrm{~cm}^{2}\end{array}$} \\
\hline & & 1 nucleus & 2 nuclei & $>2$ nuclei \\
\hline 22 & $-1-$ & 2.38 & 0.025 & 0.000 \\
\hline 23 & $-1-$ & 4.75 & 0.550 & 0.050 \\
\hline 23 & $+1-$ & 21.05 & 0.100 & 0.025 \\
\hline 24 & $-1-$ & 2.53 & 0.025 & 0.000 \\
\hline 26 & $-1-$ & 3.20 & 0.225 & 0.000 \\
\hline 27 & $-1-$ & 3.13 & 0.025 & 0.000 \\
\hline 28 & $-1-$ & 16.18 & 0.075 & 0.000 \\
\hline 36 & $-1-$ & 11.78 & 0.580 & 0.075 \\
\hline 36 & $+1-$ & 11.55 & 0.550 & 0.000 \\
\hline 48 & $+1-$ & 30.48 & 0.725 & 0.075 \\
\hline Mean value & $s+$ non-s & 10.70 & 0.288 & 0.025 \\
\hline Mean value & non-s & 6.28 & 0.215 & 0.018 \\
\hline
\end{tabular}

Table 4. Results of statistical analysis. Mann-Whitney U-test (nonparametric, independent samples)

\begin{tabular}{llll}
\hline Group & \multicolumn{3}{c}{ Mean value (cells $/ 0.000025 \mathrm{~cm}^{2}$ ) } \\
\cline { 2 - 4 } & 1 nucleus & 2 nuclei & $>2$ nuclei \\
\hline Controls & 10.70 & 0.29 & 0.0250 \\
Chest compression & 14.67 (n.s.) & 0.32 (n.s.) & 0.0188 (n.s.) \\
Strangulation/throttling & 7.66 (n.s.) & 0.11 (n.s.) & 0.0077 (n.s.)
\end{tabular}

n.s., differences not significant (significance level 95\%)

comparing the numbers of alveolar macrophages with 1,2 or more nuclei could be found between the ,asphyxiation groups" and the controls (see Table 4).

\section{Discussion}

The detection of polynuclear giant cells in the lungs of asphyxiated individuals was first described by Janssen [6] and the hypothesis that such cells in the lungs of otherwise healthy individuals indicates death by (slow) asphyxiation was confirmed in experimental animals [7]. Other authors also described polynuclear giant cells in cases of "slow" asphyxiation [9] or of traumatic asphyxia [2].

Previous studies, however, provided evidence that an apparent increase in the amount of pulmonary polynuclear giant cells in cases of strangulation, throttling or suffocation due to covering the head with plastic bags cannot be observed in comparison to individuals dying of other causes of death [1]. Other authors also found no apparent differences in the content of alveolar macrophages in cases of throttling or strangulation when compared to the controls [12].

To confirm and extend our previous results we performed a morphometrical analysis including additional cases of traumatic asphyxia due to chest compression, but found no significant differences between the various groups.

The striking differences to the results obtained from experimental animals by other authors can easily be explained by methodical factors. First it must be emphasized that it is a well known observation that experimental results cannot easily be transferred to human conditions since biological processes or reactions proceed faster in (small) animals. Furthermore, the rats and guinea pigs investigated by Janssen and Bärtschi [7] died of prolonged hypoxia of $30 \mathrm{~min}$ up to $12 \mathrm{hrs}$ duration. In our cases, however, the asphyxiation interval was considerably shorter in spite of survival times (time between accident and individual death) up to several days in the group of traumatic asphyxia. However, exact information about the duration of the chest compression, i.e. the time period between accident and freeing of the victims by the first aid teams, could not be obtained, but information from the rescue teams indicated a duration of traumatic asphyxia of less than 30-40 min (see the cases of the 36 or 38-year old males). A further aspect is that in the cases of chest compression, additional traumatic events (lung contusions, rib fractures) probably influenced the duration of the asphyxiation process so increasing the difficulties in determination of the asphyxiation interval. In cases with longer survival times, the (unsuccessful) resuscitation attempts were performed in the hospital and therefore an influence of such reanimation measures on our results seems to be of less importance. All cases of chest compression showed signs of asphyxiation, e.g. numerous petechiae in the skin and conjunctivae, confirming a major influence of the asphyxiation component as a cause of death even though it could not be decided whether they really died of slow asphyxiation.

The differences to the findings reported by other authors in cases of asphyxiated humans, however, cannot easily be explained. A considerable difference in the duration of the asphyxiation process does not seem very probable even though the exact duration in our series and in the cases of chest compression of throttling reported by Janssen [6] is unknown. The cases investigated in our study were characterized by a wide variation in individual age whereas Janssen reported cases of younger individuals. On the other hand, a considerable number of patients of our different investigation groups (strangulation/throttling - chest compression - controls) showed a comparable age but no relevant differences could be established. The considerable variation in the number of mono- and polynuclear alveolar macrophages which was observed in all groups limited the statistical evaluation but no tendency to increased numbers in cases of asphyxia occurred when compared to the controls. These considerable individiual variations, however, cannot easily be explained by methodical reasons since no apparent morphological alterations of the lungs or cases of drug addiction were observed in our series and besides an influence of former stimuli [3] we can give no other explanation.

In order to discuss the results reported by other authors it must be noticed that in our opinion most cases described by Reh [9] (coma diabeticum, chronic alcoholism, carbon 
monoxide-intoxication, epileptic seizure) were not characterized by an asphyxiation process as investigated by Janssen or in our series and can therefore not be regarded as typical examples of lethal asphyxia except if most causes of death are regarded as some form of asphyxiation. Apparent differences between the duration of chest compression in our study and the cases of traumatic asphyxia reported by Brinkmann [2] are also not probable. A relevant influence of advanced individual age, smoking or resuscitation attempts on the number of polynuclear giant cells - even though a tendency to higher numbers especially of alveolar macrophages was detectable in our series - can also be excluded since the control group in particular included younger smoking and non-smoking indivdiuals who had not been resuscitated and showed no signs of aspiration. Furthermore, the evaluation of the lungs of non-smoking individuals also revealed no relevant differences between the various groups especially in the number of giant cells. A possible influence of a different distribution of alveolar macrophages with increased contents in atelectatic regions was compensated by the random selection of 20 microscope fields per specimen and therefore does not seem to be responsible for the results.

Since other authors have neither performed a morphometrical analysis nor systematic investigations of control cases, the contrary results can - besides considerable individuals variations - in our opinion only be explained by the (unexpected) observation that polynuclear giant cells also occur in healthy, functionally normal lungs of non-asphyxiated individuals. The presence of these cells would be conceivable since their mean life-span is assumed to be approximately 81 days [11] and a development due to former stimuli such as dust inhalation, infections, aspiration etc. is very probable [3].

Therefore, the following practical conclusions for the morphological diagnosis of asphyxiation by detection of polynuclear giant cells can be drawn:

1. Polynuclear giant cells can also occur in the lungs of healthy, non-asphyxiated indivdiuals and considerable variations in the number in particular of mononuclear alveolar macrophages can be found.
2. No significant increase in the number of alveolar macrophages or polynuclear giant cells can be observed in cases of strangulation/throttling or chest compression. The duration of the asphyxiation process, at least in most of these forensic autopsy cases does not seem to be long enough to enable the development of pulmonary polynuclear giant cells as described in experimental animals with considerably longer intervals of hypoxia.

\section{References}

1. Betz P, Nerlich A, Penning R, Eisenmenger W (1993) Pulmonary giant cells and their significance for the diagnosis of asphyxiation. Int J Led Med 106:156-159

2. Brinkmann B (1978) Traumatic asphyxia: pathophysiology and pathomorphology. Z Rechtsmed 81:79-96

3. Cottier H (1980) Pathogenese, Bd. 1. Springer, Berlin Heidelberg New York

4. Cordell IL, Falini B, Erber WN, Ghosh AK, Abdulaziz Z, MacDonald S, Pulford AF, Stein H, Mason DY (1984) Immunoenzymatic labeling of monoclonal antibodies using immuno complexes of alkaline phosphatase and monoclonal anti-alkaline phosphate (APAAP-complex). J Histochem Cytochem 32: 219-229

5. Henssge C (1990) Beweisthema todesursächliche/lebensgefährliche Halskompression: Pathophysiologische Aspekte der Interpretation. In: Brinkmann B, Puischel K (eds) Ersticken Fortschritte in der Beweisführung. Springer, Berlin Heidelberg New York London Paris Tokyo Hong Kong Barcelona, pp 3-13

6. Janssen W (1963) Riesenzellbildung bei Erstickung. Dtsch Z Ges Gerichtl Med 54:200-210

7. Janssen W, Bärtschi G (1964) Vitale and supravitale Reaktionen der Alveolarzellen nach protrahiertem Sauerstoffmangel. Dtsch Z Ges Gericht1 Med 55:47-60

8. Janssen W (1977) Forensic Histopathology. Springer, Berlin Heidelberg New York

9. Reh H (1965) Die Verfettung der Alveolarepithelien beim plötzlichen Tod. Beitr Gerichtl Med XXII: 236-242

10. Sachs L (1969) Statistische Auswertungsmethoden, 2nd edn. Springer, Berlin Heidelberg New York

11. Thomas ED, Ramberg RE, Sale GE, Sparkes RS, Golde DW (1976) Direct evidence for a bone marrow origin of the alveolar macrophage in man. Science 192:1016-1018

12. Wiese J, Maxeiner H, Schneider V (1990) Histologische Lungenbefunde beim Würgen und Drosseln. In: Brinkmann B, Püschel K (eds) Ersticken - Fortschritte in der Beweisführung. Springer, Berlin Heidelberg New York London Paris Tokyo Hong Kong Barcelona, pp 158-171 